\title{
ANALYSIS OF PUBLIC HEALTH RISKS FROM CONSUMPTION OF INFORMALLY MARKETED MILK IN KENYA•
}

\author{
Omore, A.O. ${ }^{1,3}$, S. Arimi, S.M. ${ }^{2}$, Kang'ethe, E.K. $^{2}$ and McDermott, J.J. ${ }^{1}$ \\ ${ }^{1}$ International Livestock Research Institute, P.O. Box 30709, Nairobi, Kenya; ${ }^{2}$ Dept. of Vet. Public \\ Health, University of Nairobi, P.O Box 29053, Nairobi, Kenya; ${ }^{3}$ Kenya Agricultural Research \\ Institute, P.O. Box 57811, Nairobi, Kenya.
}

\begin{abstract}
Despite an unfavourable policy environment against informal milk markets, these markets account for most milk sales in Kenya. Convenient delivery and lower prices are the principal benefits for poor consumers. Current milk handling and safety regulations in Kenya are derived from models in industrialised countries. These may not be appropriate for local market conditions. An important step in targeting policies better is to collect quantitative and qualitative information about milk-borne health risks under different marketing situations. Preliminary results of assessments of milk quality and handling practices of informal milk market agents and consumers in central Kenya show very low apparent prevalence of zoonotic health hazards in milk from the smallholder herds that contribute most marketed milk. Higher bacterial counts were associated with longer market chains and distance to urban areas. Most (up to 80\%) of samples did not meet national bacterial quality standards. Over 96\% of consumers boiled milk before consumption mainly to lengthen shelf life but also for health reasons. The most important health risks were judged to be from anti-microbial residues found in up to $16 \%$ of milk samples tested.
\end{abstract}

\section{Introduction}

Despite policies to discourage them, informal milk markets account for nearly $90 \%$ of milk sales in Kenya. Informal milk market agents include farmer dairy co-operatives, small traders using bicycles and public or private transport and small retail outlets, such as dairy kiosks, and shops. Studies by the MoARD/KARI/ILRI Smallholder Dairy Project showed that convenient delivery and lower prices (reflecting lower handling and processing costs) are the principal benefits for consumers (Omore et al., 1999; MoA/KARI/ILRI, 2000). Current milk handling and safety regulations in Kenya are derived from models in industrialised countries. These may not be appropriate for local market conditions where such regulations may unnecessarily inhibit efficient milk marketing. An important step in developing targeted policies more supportive of market participation of the majority is to collect quantitative and qualitative information about milk-borne health risks under different production and marketing situations. This paper gives an over-view of studies undertaken in central and southern Kenya aimed at assessing public health risks from informally marketed milk and presents preliminary results of milk quality and handling practices of informal milk market agents and consumers.

\section{Materials and Methods}

Seasonal survey data were collected from 250 informal milk market agents and 230 households (hh) consuming raw (unpasteurised) milk in rural (Kiambu and Nakuru Districts) and urban (Nairobi City and Nakuru Town) locations between January 1999 and January 2000. These sites also represented contrasting levels of market access and types of dairy production systems. Respondents were randomly selected within production system (extensive and intensive) and human population density (urban and rural) strata. Data on milk handling practises by consumers and market agents, dairy product consumption and preferences were collected using a questionnaire. Raw milk samples were collected from each milk market agent at retail points and from each consuming household for laboratory 
assessments. In addition, 110 pasteurised milk samples were collected from retail outlets with and without chilling facilities and subjected to the same tests for comparison.

Total and coliform bacteria in the milk samples were counted using the Standard Plate Count method; brucellosis status was investigated using the Milk Ring Test (MRT) and the indirect ELISA (Nielsen et al., 1996) ${ }^{1}$; selective media and biochemical tests were used to isolate $E$. coli and E. coli 0157:H7; and, drug residues were screened using Charm AIM test kit (Charm Sciences Inc., USA) to detect $\beta$-lactams, tetracyclines, aminoglycosides, macrolides and sulphonamides at levels above maximum residue limits (MRLs) recommended by the European Union (EU).

In addition, risks of zoonotic tuberculosis were investigated through cultural and biochemical speciation of Mycobacteriaceae isolated from sputum and lymph node aspirate samples obtained from patients in Narok District suspected to be suffering from tuberculosis between April and December 2000.

\section{Results}

Consumption is mainly of liquid milk. Raw fresh milk was purchased by $29 \%$ of households in Nairobi (average $=5.5$ litres $/ \mathrm{hh} / \mathrm{month}$ ) in comparison to $93 \%$ of households in both Nakuru urban (average $=22.5$ litres $/ \mathrm{hh} / \mathrm{month}$ ) and rural (average $=24.3 \mathrm{litres} / \mathrm{hh} / \mathrm{month}$ ). The total liquid milk equivalent of pasteurised milk and processed dairy products consumed in Nairobi, Nakuru urban and Nakuru rural were 15.6, 3.8 and 0.2 litres/hh/month, respectively. Pasteurised milk was purchased in Nairobi, Nakuru urban and Nakuru rural by $78 \%, 34 \%$ and $5 \%$ of sample households, respectively. More raw and pasteurised milk was purchased as income class increased. All households in urban areas and $96 \%$ in Nakuru rural reported boiling milk prior to consumption, mainly as an ingredient in other foods, mostly tea. Most consumers expressed a preference for raw over pasteurised milk.

Milk quality as judged by total bacterial counts was generally low with $60-80 \%$ of samples collected from various market pathways, including pasteurised milk, failing to meet standards set by the Kenya Bureau of Standards (Mwangi et al., 2000). The main zoonotic health risks examined were brucellosis, coliforms and bovine tuberculosis. Interestingly, brucellosis antibody detection by ELISA varied by milk source. Br. abortus antibodies were not detected in raw milk sold in urban areas but were found at low levels (2-5\%) in milk sampled from consumers in rural areas and at higher levels (25\%) in pasteurised milk (Table 1).

Of 258 milk samples tested for faecal coliforms, $22 \%$ and $1 \%$ contained E. coli and E. coli 0157:H7, respectively. This mirrored the high bacterial counts found milk samples collected from informal milk agents. No M. bovis was found and the sampling strategy applied implies that one can be $95 \%$ confident that the maximum prevalence of bovine TB in the district is not greater than $2 \%$ (Koech, 2000).

\footnotetext{
1 The ELISA test is more sensitive (96.5\%) and specific $(>99.5 \%)$
} 
Table 1. Proportions of raw milk samples from consumer households and various market agents in rural and urban areas in Kenya testing positive for $\mathrm{Br}$. abortus using MRT and ELISA antibody tests.

\begin{tabular}{|c|c|c|c|c|c|c|}
\hline \multirow[b]{2}{*}{ Source of milk } & \multicolumn{3}{|c|}{ Antibody Prevalence - Season 1} & \multicolumn{3}{|c|}{ Antibody Prevalence - Season 2} \\
\hline & $\begin{array}{l}\text { Number } \\
\text { tested }\end{array}$ & $\begin{array}{l}\text { MRT } \\
\text { Positive } \\
\%\end{array}$ & $\begin{array}{l}\text { ELISA } \\
\text { Positive } \\
\%\end{array}$ & $\begin{array}{l}\text { Number } \\
\text { tested }\end{array}$ & $\begin{array}{l}\text { MRT } \\
\text { Positive } \\
\%\end{array}$ & $\begin{array}{l}\text { ELISA } \\
\text { Positive } \\
\%\end{array}$ \\
\hline Urban consumers & 105 & 9.5 & 0 & 107 & 0 & 0 \\
\hline Rural consumers & 106 & 5.6 & 1.8 & 114 & 0.8 & 4.8 \\
\hline Informal market agents & 239 & 3.3 & 5 & 239 & 1.2 & 4.2 \\
\hline Formal market agents & 110 & - & 25 & - & - & - \\
\hline
\end{tabular}

An important health risk that heat treatment of milk cannot eliminate is from anti-microbial residues in milk. Residues exceeding EU MRLs were detected in 4-16\% and 8\% of informally traded and pasteurised milk samples, respectively (Figure 1).

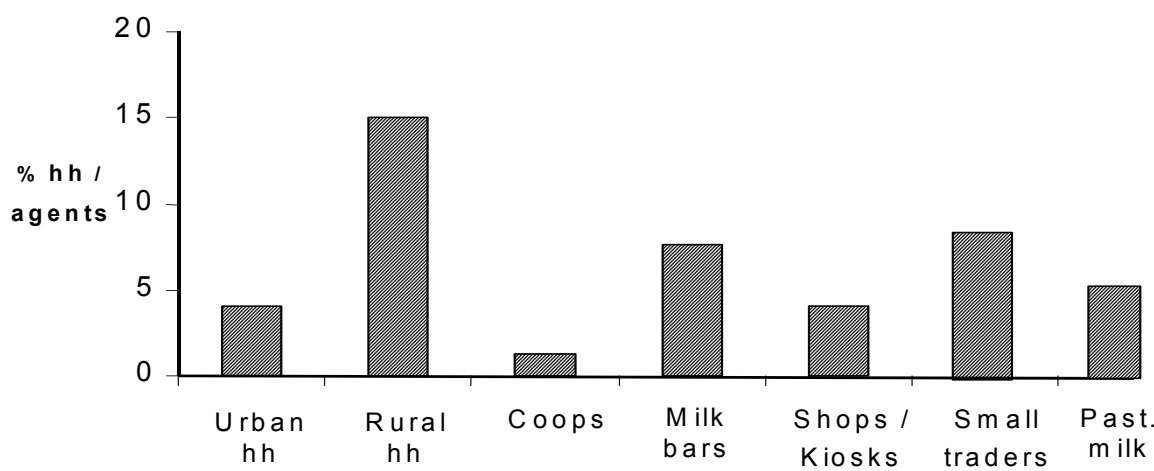

F ig u re 1. P roportion $\mathrm{s}$ of $\mathrm{m}$ illk $\mathrm{sam} \mathrm{ples} w$ ith a $\mathrm{n}$ tib io tic and a tib a c teria 1 residues above E U m axim um residue lim its (M R L s )

\section{Discussion}

The variation in detection of brucellosis reflects past findings that show high variation of the disease by cattle production systems (Waghela, 1976; Kadohira et al., 1997). Over 70\% of marketed milk in Kenya is from smallholder herds without brucellosis (Kadohira et al., 1997). The results indicate that bulking of milk from many areas and production systems could pose significant health risks if the milk is not pasteurised or adequately boiled. The non-detection of M. bovis in Narok District in this study and a similar recent report from a study conducted in North-Eastern Province (Githui et al., 2000) seem to vindicate the long held official position indicating absence of bovine tuberculosis in Kenya. However, the findings need to be verified in other areas and periodically given the risk posed by movement of pastoral livestock across borders.

The high bacterial counts mainly reflect poor hygiene and a long time-lag between milking and sale of the milk (Mwangi et al., 2000). Future efforts will focus on improving milk quality by informal market agents by training and extension on appropriate handling containers, milk temperature regulation and other factors. Of greatest risk in this regard is raw milk purchased from multiple-source markets, often at great distances. Market agents who currently bulk and retail raw milk could reduce health risks by processing or screening their milk prior to sale. Actual health risks from bacterial contamination are already judged to be low because of the common consumer practice of boiling milk before consumption, a 
practice that should be further encouraged. This practice may decrease the need for strict implementation of regulations preventing raw milk marketing.

Of concern is the high proportion of samples with drug residues above EU MRLs. This suggests that many farmers do not observe prescribed withholding times. Market agents may also use anti-bacterials to increase milk storage time. Further studies will determine which drugs are involved and when and how they are administered.

Many studies on zoonoses in Kenya have focussed at the farm-level without assessing actual risks to consumers and the market risk factors involved. Information from this study will be combined with economic data on market efficiency, and recommendations developed to manage the health risks found and to achieve the objective of supporting dairy markets serving resource-poor producers without impeding the efficient marketing of milk. The recommendations will thereafter be communicated to all concerned through a process that will include facilitation of productive interactions between policy makers and stakeholders to achieve the above objective. The recommendations will not only inform policy decisions in Kenya but also in the many developing nations with similar circumstances.

\section{References}

1. Githui, W. A., Hawken, E. S., Juma, E. S., Godfrey-Faussett, P., Swai, O. B., Kibuga, D. K., Porter, J. D. H., Wilson, S. M. and Drobniewski, F. A. (2000). Surveillance of drugresistant tuberculosis and molecular evaluation of transmission of resistant strains in refugee and non-refugee populations in North-Eastern Kenya, Int. J. tuber. Lung Dis., 10: 947- 955.

1. Kadohira, M., McDermott, J.J., Shoukri, M.M. and Kyule, M.N. 1997. Variations in the prevalence of antibody to brucella infection in cattle by farm, area and district in Kenya. Epid. \& Infection 118:35-41.

2. Koech, K. R. (2000). MSc. Thesis. Investigation of M. bovis from human tuberculosis cases from Narok District, Kenya. University of Nairobi. In press.

3. MoA/KARI/ILRI. 2000. Smallholder Dairy Project: Proceedings of Phase 1 Achievements Seminar held at the Kenya Agricultural Research Institute Hqs. March 2000. 32pp.

4. Mwangi, A., Arimi, S.M., Mbugua, S., Kang'ethe, E.K. and Omore, A.O. 2000. Assurance of marketed milk quality in Kenya. Paper in these Proceedings.

5. Nielsen, K., Smith, P., Gall, D., Cosma, C.,Mueller, P., Trottier, J., Cote, G., Boag, L. and Bosse, J. 1996. Development and validation of an indirect enzyme immunoassay for detection of antibody to Brucella abortus in milk. Veterinary Microbiology 52:165-173.

6. Omore A.O., Muriuki, H., Kenyanjui, M., Owango, M. and Staal, S. 1999. The Kenyan Dairy Sub-Sector: A Rapid Appraisal: Research Report of the MoA/KARI/ILRI Smallholder Dairy (R\& D) Project. International Livestock Research Institute. Nairobi (Kenya).51pp

7. Waghela, S. 1976. Animal brucellosis in Kenya: a review. Bull. Anim. Hlth. Prod. Afr. 24:53-59.

- Acknowledgements: British Department for International Development for financial assistance 